\title{
The Future of Knowledge Management
}

\author{
Ilkka Tuomi \\ Visiting Scientist \\ Joint Research Center, Institute for Prospective Technological Studies \\ llkka.Tuomi@jrc.es \\ 22 May 2002
}

published in:

Lifelong Learning in Europe (LLinE), vol VII, issue 2/2002, pp. 69-79 


\section{The Future of Knowledge Management}

\section{Introduction}

Knowledge management emerged on the maps of strategy consultants and conference organizers around 1995. For a few years, it was the next big thing after business process reengineering and total quality management. It overlapped with initiatives on competence management and organizational learning, gaining credibility from the daily news on the imminent arrival of the knowledge society and the continuously expanding Internet. The early emphasis in knowledge management was on information systems. Then the focus shifted towards organizational development, intellectual capital management, and competence management. Towards the end of the 1990's, social learning, organizational sensemaking, and systemic innovation and change management became prominent themes in knowledge management.

In the next years, knowledge management theorists and practitioners will find themselves asking how revolutions can be managed. If knowledge is power, where are the limits of organizational knowledge creation? If organizational learning and innovation imply emancipation of knowledge workers and constant reorganization of organizational competencies, how the new knowledge-based organization should be organized? Do we need a new "organizational constitution" that redefines rights, responsibilities, and relations of knowledge workers and employers? Should we, perhaps, reconsider the goals of lifelong learning and educational systems in a world where knowledge is well managed and creative destruction dominates?

To address these questions, it is useful to rediscover the sources of knowledge management. Where did knowledge management come from and where it is going?

In this article, I characterize the main sources of knowledge management movement, show how the various generations of knowledge management succeeded each other, summarize some of the learnings, and propose some future research, policy, and management issues.

\section{The sources of knowledge management}

Knowledge management has its origins in four different disciplines that were relatively independent until the late 1990's. The broad discussion on the emerging knowledge society provided credibility for each of them, emphasizing the importance of the new rules of global, networked, and knowledge-intensive economy. Each of the four different disciplines gained momentum from the perceived ongoing transformation, indirectly amplifying each other.

Below, I characterize these four disciplines of knowledge management as organizational information processing, business intelligence, organizational cognition, and organizational development. The first had its starting point in computer technology, the second on information services, the third on research on organizational innovation, learning, and sensemaking, and the fourth on business strategy and human resource management. 
History is always a narrative reconstruction and requires simplification. To understand the developmental paths and future potential research issues of knowledge management, it is, however, useful to recall the sources of knowledge management, also in this somewhat simplified form.

\section{Organizational information processing}

During the last two decades, knowledge management has often been associated with computers and information systems. Indeed, during the first generation of knowledge management, many initiatives focused on finding a suitable software package that could be used to make knowledge management happen. Software vendors who quickly repackaged their existing products as knowledge management systems strengthened this belief in technology. The idea that information systems were a key to corporate future gained credibility from popular press, and this belief was rarely questioned. Often it also seemed that the concept of knowledge easily led to lengthy theoretical discussions. Software packages, in contrast, were something concrete and real. In early knowledge management initiatives, project progress was often measured by counting software licenses.

The implicit idea in the computer-oriented initiatives was that the core problem with knowledge management was in storing and sharing of knowledge. The belief that knowledge could and should be represented in and shared with computer systems was itself based on a long tradition of research. We might call it "the revenge of AI."

In the early 1970s, research on artificial intelligence to a large extent had rejected its original goal of finding generic and universal rules that produced intelligence. After some early successes in the 1950s and 1960s, researchers became convinced that intelligence required domain specific knowledge. This, in turn, required new approaches in representing knowledge in forms that could be processed by a computer. As a result, in the 1970s the focus in AI research moved to systems that followed a relatively simple logic but which had detailed knowledge of their domain of application (McCorduck, 1979).

In the 1980s, the increasing processing power and some widely published success stories resulted in extensive interest in expert systems and knowledge-based technology. The idea that human expertise could be represented in a computer system and made available whenever and wherever needed became a commonplace truth. Expert systems were marketed as solutions to alleviate the problems of organizational downsizing, retirement of experts, and loss of critical competencies (e.g., Feigenbaum, McCorduck, \& Nii, 1988).

Knowledge representation techniques that were developed for expert systems were also understood to be of generic value in accurate classification of human knowledge. By representing knowledge in forms that had been developed for computers, also human knowledge was supposed to be exactly represented and its inaccuracies were to be detected and corrected. Michie (1983), one of the thought leaders of the knowledge-based systems movement, for example, proposed a computer-based "knowledge refinery" that was intended for codifying and synthesizing knowledge from multiple sources. According to Michie, in the emerging knowledge society 
knowledge refineries were to become as central an industry as the oil refineries were in the industrial age.

The focus in artificial intelligence research in the 1970s and 1980s was on automated processing of knowledge (e.g. Bobrow \& Winograd, 1977). The increasing capability to store information, however, also made possible new forms of document and database management systems. One of the most popular ideas in the 1980s was hypertext. For example, Akscyn and his colleagues (Akscyn, McCracken, \& Yoder, 1988) developed a "Knowledge Management System," also known as KMS, an interactive and collaborative hypermedia system, which become a key inspiration for the World Wide Web. The KMS was a commercial version of an earlier hypertext system, ZOG, developed at the Carnegie-Mellon University since 1972. KMS was used, for example, to manage the large amounts of manuals at aircraft carriers.

Research on software architectures that could effectively support complex organizational decision-making also led to various attempts to build large corporatewide information repositories. The hope was that eventually such repositories could contain all the data that was needed for rational and fact-based management.

Management information systems, MIS, were to be built on top of enterprise models, and the information was to be represented in forms that also the top management could understand. According to the more futuristic accounts, management was to be supplied with command and control systems that resembled fighter jet cockpits or high-tech war rooms. More modest systems appeared commercially as executive information systems, or EIS (Watson, Rainer, \& Koh, 1991). The underlying database structures were to allow rapid analysis of different decision scenarios, requiring multidimensional databases and tools for interactive online analytical processing. The implicit assumption in EIS research was a somewhat traditional hierarchical information-processing model: the important information processing tasks were supposed to happen at the top of the organization.

Towards the end of the 1980s, some researchers started to emphasize the communicative and collaborative possibilities of information systems. In part this was related to the increasing visibility of computer networks. For example, Terry Winograd, one of the central figures in the emergence of the knowledge-based offspring of AI, went on to develop an influential workflow system, the Coordinator (Flores, Graves, Hartfield, \& Winograd, 1988; Winograd \& Flores, 1986), which utilized Searle's speech-act theory. Various alternative models to describe and implement organizational workflows and communication processes were developed (e.g. Auramäki, Lehtinen, \& Lyytinen, 1988; Lamersdorf, 1988), gradually leading to broader concepts computer supported collaborative work, computer-mediated communication, groupware, and collaboration systems.

In general, the "hard" AI was inspired by a relatively straightforward positivistic epistemology and a cognitivistic information processing view on human intelligence. Within this tradition, the nature of knowing was rarely questioned. Knowledge was expected to be explicit, structured, organized in taxonomies, and semantically unambiguous. The communicative approach to information systems, on the other hand, quickly led to more social constructionistic and phenomenological epistemologies. 


\section{Business intelligence}

Whereas information systems and computers were often perceived as the core substance of early knowledge management initiatives, early on it was also noted that organizations had managed their knowledge already for a long time. For example, corporate information services and libraries had employed people who were professionals in categorizing, searching, and distributing knowledge. The increasing competitive pressures had in particular increased the importance of competitive analysis. As a result, large corporations had set up competitive intelligence units, often closely associated with company information and library services (Gilad \& Gilad, 1988; Stanat, 1990; Ghoshal \& Westney, 1991).

The focus in competitive intelligence was on strategic analysis of external information related to market trends and competitors (Aguilar, 1967; Porter, 1980; Fuld, 1996). Whereas the information processing experts often approached organizational knowledge as a technical problem that could be solved by appropriate use of computers, the problem for competitive intelligence people was in finding, understanding, synthesizing, and disseminating relevant information. At first, this intellectual work was assigned to back-office specialists. Their work was greatly facilitated in the early 1990's when online access to external databases and news services became widely available. Suddenly, it was possible to know in real time everything that competitors and customers were doing, anywhere around the world. For a while, the dream of perfect information had become true.

Soon, however, it was discovered that perfect information leads to information overload. As a result, systems that could categorize information based on user needs were actively studied. Researchers tried to develop domain specific ontologies, thesauri, and conceptual models that could be used as the basis for categorizing information and organizational messages. Although the motivation for developing conceptual models and categorization tools was to improve human information processing instead of automatic processing, information technology obviously played an important role also here. For example, at MIT, Tom Malone and his colleagues developed an "information lens" that was supposed to filter and prioritize documents and messages relevant to the user (Malone, Grant, et al., 1987), and argued that a new "science of coordination" was about to emerge (Malone \& Crowston, 1994).

Whereas the original focus on competitive intelligence was on top management strategic decision-making, the expanding computer networks made it obvious that organizational intelligence exists also outside executive offices and boardrooms. Indeed, in a rapidly changing competitive environment the most valuable knowledge was often distributed among the members of the organization. Moreover, top management often didn't know who had the critical knowledge. This, again, led to an emphasis of the communicative aspects of organizational information processing. As a result, the back-office competitive intelligence analysts started to redefine themselves as business intelligence professionals. Instead of decision-making based on pre-analyzed reports and data, knowledge sharing became the central issue for business intelligence people. Instead of information objects, organizational knowledge was now in information flows. 
This observation also highlighted a contrast between two views on organizational knowledge. According to the mainstream information processing view, knowledge was data and facts that were independent of people and their interpretations. This implicit assumption made it natural to think that knowledge can be stored in computers. Business intelligence systems, however, started to evolve toward heterogeneous systems comprised of networked humans and machines. Information objects were viewed as enablers of organizational knowledge processes. As such, they perhaps facilitated organizational knowing. The critical question, however, was how the organizational knowledge flows should be organized so that the organization remained well informed. Relevance, a concept that conventionally remained beyond the limits for traditional information processing, became a key issue for business intelligence professionals.

Technology, however, pushed itself strongly to the center of organizational spotlights, creating what one might call a temporary backlash in business intelligence. As the World Wide Web exploded in the public consciousness around 1994, Tim BernersLee's original vision of the Web was rediscovered again and again: when all documents would be on the Web and every document would be linked to every other possible document, the world could become a better place. Knowledge would be free, and available when needed.

Business intelligence professionals naturally had some reservations concerning this idea. They had learned, for example, that sometimes it was useful to keep information secret. Another lesson was that to be useful, information had to be "actionable." Even the best analysis was of no value if it remained on the analyst's shelf or if the management was not able to do anything with the information it contained (Fuld, 1996). Relevance was lost, but gradually found again. Indeed, the early enthusiasm with the Web often quickly disappeared into those mysterious black holes of cyberspace where time seemed to stop and ancient organizational history still was ongoing reality.

The World Wide Web didn't have any effective means to manage access rights or content and it didn't have any support for making information actionable. In one sense it did, however, continue a tradition that had contested the mainstream artificial intelligence since early 1960's. Whereas Herbert Simon and the other pioneers of AI believed that the future of computers was in intelligent processing of information, Douglas Engelbart argued that computers were a new medium that could augment human though processes. Engelbart's Augmentation Research Center at Stanford Research Institute became one of the hot spots of innovation in computer technology, leading development in interactive computing, graphical user interfaces, and collaboration systems. The World Wide Web took this augmentation system concept to its ultimate logical end: it reduced the problem of knowledge representation to minimum by assuming that all knowledge can be represented as documents and associations between them. And the software of the World Wide Web didn't have any intelligence whatsoever. It left all the theoretical and practical problems of thinking and sensemaking to its users.

In hindsight, one could say that this was a wise choice. After all, although we don't know what knowing exactly is, humans do it all the time. 


\section{Organizational cognition}

Corporate competitive intelligence expanded to business intelligence at the beginning of the 1990's when it reconceptualized its task to include the management of organization's internal knowledge. Although business intelligence relied heavily on information systems, its focus was not on knowledge representation and automated processing; instead, it focused on effective utilization of human experts, expert analysis, and social and communicative networks. Here it came close to the third source of knowledge management: research on organizational cognition and sensemaking.

Research on organizational cognition was historically inspired by the same information processing view that was the foundation of cognitivistic theories of human mind (Knight \& McDaniel, 1979; Tushman \& Nadler, 1978; Egelhoff, 1988). Aligned with this tradition, which originally conceptualized organizations as hierarchical information processing machines, the early research on organizational cognition focused on top management decision making (Ungson, Braunstein, \& Hall, 1981).

Although the information processing view was widely accepted, more sociologically oriented researchers early on adopted a more interpretationistic approach. For example, Karl Weick and his colleagues published several important articles that became landmarks in organizational cognition research, introducing constructivistic ideas in organization science (e.g., Bougon, Weick, \& Binkhorst, 1977; Daft \& Weick, 1984; Weick, 1995). This research highlighted the fact that organizational knowledge is not something that can be objectively recorded and stored in databases; instead, organizational knowing is an active process where people try to make sense of their environment.

Most clearly the active process of knowledge construction became visible in organizational innovation studies. In this area, the limitations of the mainstream information processing view and its underlying epistemology were difficult to dismiss. Indeed, the cognitivistic view on organizational information processing didn't really make much sense when it was applied to innovative organizations where machine-like predictability and efficiency were not the primary concerns. Such organizations, by their nature, were constructing products and processes and related knowledge that did not exist before. The empiristic epistemology that was the core of the information processing view and its upgraded form, trivial constructivism, became inadequate in practice. Innovation appeared as chaos and as something that good managers should avoid at all costs.

Perhaps just because of that, a key contribution to organizational innovation research came from outside the US strongholds of organizational science. Ikujiro Nonaka (1994; Hedlund \& Nonaka, 1991) reminded organizational researchers that there were alternatives to the positivistic epistemology of the mainstream information processing view. In particular, Nonaka (1988) noted that organizations are not machines that can be streamlined to their maximum information processing efficiency without losing much of their knowledge creation capabilities. Just when the good American management practice was getting ready for the ultimate streamlining of organizational information flows and removal of unnecessary layers of middle-management, 
unorganized randomness, and, in general, everything that was not directly adding value to the business processes, Nonaka highlighted the point that this route would be fatal for knowledge-based companies.

Nonaka's innovation studies were complemented and to some extent paralleled by research on organizational learning. At deeper levels, however, Nonaka's approach was based on a more radical epistemological position than, for example, Argyris and Schön's (1978), or Senge's (1990) constructivistic and system-theoretic models of organizational learning. Although Schön (1987), in particular, had emphasized the importance of tacit and situational knowledge in learning, and the pragmatic nature of knowing and knowledge generation (Schon, 1963), in Nonaka's work the concept of tacit knowledge was tightly linked to phenomenological epistemology. More specifically, it was linked to an epistemology that came from the Kyoto school of philosophy, launched by Kitaro Nishida at the beginning of the $20^{\text {th }}$ century. The Kyoto epistemology was a synthesis of Asian views of reality and knowing and Western phenomenological philosophies, inspired by William James, Henri Bergson, John Dewey, Edmund Husserl, and Martin Heidegger, among others (Nishitani, 1991; Tuomi, 2002: ch. 5). But, of course, managers were not supposed to be interested in such philosophical details.

\section{Organizational development}

As noted, computer people were looking for a technical solution for the problem of organizational knowledge and business intelligence people were trying to provide relevant information in a timely fashion within the organization. Organizational cognition researchers, however, started to question the nature of knowing and its role in organized social action. It was only a small step to move from descriptions of organizations as knowledge based entities to their actual reorganization. If organizations had to be effective in using and creating knowledge, perhaps they should look different than the traditional industrial bureaucracies. Perhaps it could be possible to create learning organizations and manage their knowledge creation processes? Indeed, Nonaka and other researchers interested in organizational learning already made this transition. Others quickly followed. This linked knowledge management to business strategy.

Business strategy had since the 1960s focused on effective resource allocation and analysis of competitive strengths and weaknesses. Knowledge entered the picture relatively late. The resource-based view evolved to competence-based strategies (Quinn, 1992; Prahalad \& Hamel, 1990; Barney, 1997), organizational memory (El Sawy, Gomes, \& Gonzalez, 1986; Walsh \& Ungson, 1991), analysis of knowledgebased strategy (Gupta \& Govindarajan, 1991; Earl, 1994; Hedlund, 1994) and eventually, to the knowledge-based view of the firm (Grant, 1996; Spender, 1996).

In parallel, intellectual capital movement emerged from a more economically oriented view, arising from the observation that knowledge was invisible in organizational accounting and measurement systems (Miller, 1996; Sveiby, 1997; Edvinsson \& Malone, 1997). At first, intellectual capital people focused mainly on the management and measurement of knowledge-related competencies, with relatively little emphasis on knowledge generation and learning. The organizational customers for intellectual 
capital ideas were typically people interested in corporate finance, control, and management accounting. The strategic concern was maximum return on investment in existing knowledge assets, as well as protection of intellectual property. In itself, the idea of intangible assets and intellectual capital was not new, having predecessors, for example, in the human capital accounting attempts (Kiker, 1966) and economic theory (Tobin, 1978). The emerging knowledge economy, however, made it obvious that intangible assets could not be neglected anymore. Furthermore, the new knowledge accounting highlighted the value of social networks, customer relationships, and learning that was embedded in organizational procedures and systems.

Whereas core competence strategies and intellectual capital accounting emphasized the organizational level, human resource development started from the more concrete level of individual skill management. In the tradition of human capital accounting, the hope was to aggregate individual level skills so that they could be linked to the strategic needs of the organization. The basic assumption was that management should know what competencies were available in the organization and what competencies were needed to implement the selected business strategy. The human resource people were then supposed to help fill in critical competence gaps by supporting the upgrading of skills and recruiting people with required skill profiles. In this way, the intellectual capital accounting and organizational learning approaches were connected together.

An inherent conceptual problem in skill and competence management systems was, however, their assumption that skills could be described, analyzed, and accounted for. To get a sufficiently small list of organizational skills, skills often had to be abstracted from their concrete settings to the extent that it was sometimes difficult see whether the abstract skill actually corresponded with any capability. As the internal and external validity of skill categories was often questionable, the hope for creating sophisticated intellectual capital accounting systems based on this data quickly evaporated. Moreover, skill definitions often missed core situational and contextual factors that played important role in organizational activity. As many important organizational skills are dynamic and are only learned when they become relevant, extensive cataloguing of skills was of no help in dynamic environments and innovation management. Furthermore, many important competencies are socially distributed and reflect the capability to mobilize resources in social networks. The capability to get things done in an organizational setting often depends on the ability to bring together complementary resources and competencies, without actually having or possessing them. Conceptually, therefore, skill management had limitations. Its focus was too individualistic and it missed the social nature of knowledge and organizational action.

The importance of situational and social factors in organizational knowing had been noted since the late 1980s. In particular, the Xerox Palo Alto Research Center, and its spin-off, Institute for Research on Learning, played an important role in this area (Orr, 1990; Suchman, 1987; Brown \& Duguid, 1991; Lave \& Wenger, 1991). The research at Xerox PARC and IRL integrated ideas from ethnographic organizational studies, social interactionism, and, to a more limited extent, also from the Vygotskian cultural historical activity theory. 


\section{Summary of knowledge management disciplines}

It is obviously clear that the sources of knowledge management thinking, as described above, had many overlaps. The empirical basis for clustering these different sources or "disciplines" of knowledge management can, however, be found by looking the different communities of practice that were involved. In the mid-1990s, conferences on organizational learning and cognition, business intelligence, and organizational information systems attracted quite different audiences. The concept of knowledge management was sometimes connected with databases, intranets and document management systems, corporate accounting, learning, business strategy, and management of product development processes. This reflects the reality: instead of one well-defined knowledge management discipline there were many. Instead of one "knowledge management", we, therefore, need several characterizations, which all remain somewhat ambiguous, overlapping, and depend on the point of time which we use. The four main knowledge management clusters are summarized in Table 1. The time period underlying Table 1 is about 1993-1996. This period we might call the first generation of knowledge management.

Table 1. Sources of knowledge management.

\begin{tabular}{|l|l|l|}
\hline KM cluster & Focal root communities & $\begin{array}{l}\text { Primary object of } \\
\text { intervention }\end{array}$ \\
\hline $\begin{array}{l}\text { Organizational information } \\
\text { processing }\end{array}$ & $\begin{array}{l}\text { Information systems } \\
\text { support, AI experts, } \\
\text { software providers }\end{array}$ & Information systems \\
\hline Business intelligence & $\begin{array}{l}\text { Corporate librarians, } \\
\text { competitive intelligence } \\
\text { professionals }\end{array}$ & $\begin{array}{l}\text { Strategic decision-making } \\
\text { processes }\end{array}$ \\
\hline Organizational cognition & $\begin{array}{l}\text { Researchers on } \\
\text { organizational sense- } \\
\text { making }\end{array}$ & $\begin{array}{l}\text { Organizational knowledge } \\
\text { processing }\end{array}$ \\
\hline $\begin{array}{l}\text { Organizational } \\
\text { development }\end{array}$ & $\begin{array}{l}\text { Competence strategists, } \\
\text { innovation managers, } \\
\text { human resource } \\
\text { developers, finance \& } \\
\text { control }\end{array}$ & $\begin{array}{l}\text { Organizational capabilities } \\
\text { and management practices }\end{array}$ \\
\hline
\end{tabular}

Knowledge management was a new synthesis of several elements, and as such, it could not have been defined using available conceptual distinctions. The interest in knowledge management created a new community of experts who had their own language and expertise. This "second generation" of knowledge management started to emerge around 1997 with many corporations setting up new jobs for knowledge management specialists and "chief knowledge officers". The different sources of knowledge management became combined and also quickly absorbed to everyday organizational discourse. Indeed, today it is increasingly common to argue that knowledge management was just a hype of the 1990s, which disappears as its core ideas become integrated into organizational routines. 
What, then, will remain of knowledge management? Did we already exhaust its energy? Or are we, perhaps, only about to find its essence? In the following, I will argue that we still have a long way to go.

\section{The third generation of knowledge management}

Based on the discussion above and with gross simplification, the first generation of knowledge management could then be characterized as being focused on information sharing, information repositories, and intellectual capital accounting. The second generation brought in the concepts of tacit knowledge, social learning, situated and embedded knowledge, and communities of practice. On a more practical level secondgeneration knowledge management emphasized that knowledge management is about systemic organizational change where management practices, measurement systems, incentives, tools, and content management needed to be co-developed (Tuomi, 1999).

Future is always already present, although usually in a laboratory scale. We could therefore ask where knowledge management is going, and how its third generation will look like.

In the increasingly informationalized society, the first generation knowledge management will stay well and alive. It focused on information storage and access. Wireless networks, information processing capabilities embedded into everyday environments, and the expanding possibilities for distributed information storage and processing will guarantee that technological issues will remain important.

Here, however, the purely technology-centric view will give room for a more social understanding of technology. For example, as Lessig (1999) has pointed out, many policy and regulatory decisions are implemented through technical architectures. For instance, the alternative ways to manage digital identities, information access, security, intellectual property rights, and repudiation of electronic agreements will be hardwired to information systems architectures. This will make knowledge management technology a social, political, and ethical topic.

Simple AI-inspired automated processing systems, such as social filtering, recommendation, and data mining systems will also become increasingly sophisticated. Multimodal interfaces that handle speech, images, gestures, and text, will be widely used.

The second generation of knowledge management, however, revealed that this is not enough. In particular, conventional computers are notoriously bad in handling tacit and situational knowledge. In the future, computer systems will therefore provide contextual information and non-intrusive cues that support user's sensemaking processes. As sensemaking often requires active exploration of unknown domains of knowledge, information systems are in the future perceived as resources for knowledge construction and as tools that augment human thinking. This constructionistic view also highlights the fact that knowledge acquisition is always a learning process. As learning, in turn, is fundamentally an interactive social phenomenon, information systems will support also the mobilization of social 
resources as a part of the learning process. Instead of human capital accounting, the focus will be on active development of social capital.

In the third generation knowledge management, knowledge representations will be used increasingly as boundary objects around which knowledge processes can be organized. Instead of the empiristic attempt to store knowledge in information systems, knowledge will be viewed in a constructionistic and pragmatic perspective. Good knowledge will be something that allows flexible and effective thinking and construction of knowledge-based artifacts.

The third generation will also emphasize the link between knowing and action. Here it will, however, hit the basic constraint of all social systems. To make knowledge real, it is not sufficient that one single individual knows and acts based of her knowledge. All knowledge is inherently social and cultural, and organizational knowledge can only be realized through change in organizational activity and practice. Knowledge creation implies social revolution.

A third generation knowledge managed organization would have organizational learning, knowledge creation, and innovation processes built into its structure. As a consequence, such an organization would import the Schumpeterian creative destruction inside the focal organization, putting it into a constant state of instability and unpredictability. Managers should then learn to manage with limited control and incomplete information. To limit the associated risks, new organizational and institutional structures will be needed.

Perhaps this is one of the reasons why knowledge management pioneers, such as Nonaka, are now looking for routines and disciplines of knowledge creation. To manage, organizations have to be made predictable. In innovation ecology predictability, however, equals death. The future of management, therefore, lies in strategic allocation of chaos, risk, and uncertainty, combined with predictable and efficient execution of production. The capability to flexibly and rapidly reconfigure and generate competencies is becoming a core competence of the corporation.

\section{Knowledge management for the new economy}

It is not clear what kind of organizations will survive in this environment or what types of learning will be central. Perhaps we will see increasingly large multinational corporations as Schumpeter predicted decades ago. Or perhaps the hot boiling pot of Silicon Valley will be the augur for the future, with its lightning-speed creation, destruction, and recombination of business models. Maybe work-related competencies are in the future increasingly created by quick and well-timed traversal through concentrations of social networks -- perhaps still called organizations or business firms -- which appear and disappear as bubbles in a boiling kettle.

The increasingly dynamic internal and external environment of organizations results from the growing intensity of knowledge generation in and around organizations. As innovation-based competition is becoming increasingly important, the traditional Weberian hierarchy that was based on a relatively stable division of labor is becoming outdated. This has also implications outside organizations. For example, the 
institutional and legal basis for employer-worker relationship was based on the idea that workers sell their labor force by physically moving it to the workplace as needed, and that the boundary between work and non-work is easy to define. Today, knowledge workers don't sell their hands but also their brains. Often the creative nature of work requires that the soul will follow. Organizations are rapidly becoming perhaps the most important places for learning work-related competencies and developing social capital that makes workers employable. Perhaps we therefore will also need a new constitution that defines the mutual responsibilities and rights in the worklife.

Work, politics, economy, and the domain of private life have been understood and organized in different ways in different times. As Arendt (1998) noted, modern industrial society has been a very special configuration of them. When we move towards the innovation based economy and knowledge society, they will be reconfigured once again. Social change will be predominant. The third generation of knowledge management will require capability to manage change, social conflict, and revolution. It will require organizational forms that make ongoing revolution possible without excessively destroying accumulated knowledge assets and social capital or decapitating revolutionaries in the process. It will also require new institutional foundations that make productive conflict resolution possible. It will therefore also require that we understand better the cultural basis of knowing and social activity, as well as the ways in which social and organizational learning lead to new social practices.

\section{About the Author:}

Dr Ilkka Tuomi is currently Visiting Scientist at the European Commission's Joint Research Centre, Institute for Prospective Technological Studies, Seville. From 1987 to 2001 he worked at the Nokia Research Center in various positions in the areas of knowledge technology, strategic management, business intelligence and collaboration systems, and most recently as Principal Scientist, Information Society and Knowledge Management. From June 1999 to December 2000, he was Visiting Scholar at the University of California, Berkeley. His most recent book, Networks of Innovation: Change and Meaning in the Age of the Internet (Oxford University Press, 2002), links innovation theory with theory of knowledge creation. 


\section{References}

Aguilar, F. (1967). Scanning the Business Environment. New York: Macmillan.

Akscyn, R.M., McCracken, D.L., \& Yoder, E.A. (1988). KMS: a distributed hypermedia system for managing knowledge in organizations. Communications of the ACM, 31 (7), pp.820-835.

Arendt, H. (1998). The Human Condition. Chicago, Il.: The University of Chicago Press.

Argyris, C., \& D. Schön. (1978). Organizational Learning. Reading, MA: Addison-Wesley.

Auramäki, E.E., Lehtinen, K., \& Lyytinen, K.J. (1988). A speech act based office modeling approach. ACM Transactions on Office Information Systems, 6 (2), pp.126-52.

Barney, J.B. (1997). Gaining and Sustaining Competitive Advantage. Reading, MA: Addison-Wesley Publishing Company.

Bobrow, D.G., \& Winograd, T. (1977). An overview of KRL, a knowledge representation language. Cognitive Science, 1, pp.3-46.

Bougon, M.G., Weick, K.E., \& Binkhorst, D. (1977). Cognition in organizations: an analysis of the Utrecht Jazz Orchestra. Administrative Science Quarterly, 22, pp.606-39.

Brown, J.S., \& Duguid, P. (1991). Organizational learning and communities of practice: toward a unified view of working, learning, and innovation. Organization Science, 2, pp.40-57.

Daft, R.L., \& Weick, K.E. (1984). Toward a model of organizations as interpretation systems. Academy of Management Review, 9, pp.284-95.

Earl, M.J. (1994). Knowledge as strategy: reflections on Skandia International and Shorko Films. In C. Ciborra \& T. Jelassi (Eds.), Strategic Information Systems: A European Perspective. (pp. 5369). Chichester: John Wiley \& Sons Ltd.

Edvinsson, L., \& M.S. Malone. (1997). Intellectual Capital: Realizing Your Company's True Value by Finding its Hidden Brainpower. New York: HarperBusiness.

Egelhoff, W.G. (1988). Organizing the Multinational Enterprise: An Information-Processing Perspective. Cambridge, MA: Ballinger.

El Sawy, O.A., Gomes, G.M., \& Gonzalez, M.V. (1986). Preserving institutional memory: the management of history as an organizational resource. Academy of Management Best Paper Proceedings, 37, pp.118-22.

Feigenbaum, E.A., P. McCorduck, \& P. Nii. (1988). The Rise of the Expert Company. New York: Times Books.

Flores, F., Graves, M., Hartfield, B., \& Winograd, T. (1988). Computer systems and the design of organizational interaction. ACM Transactions on Office Information Systems, 6, pp.153-72.

Fuld, L.M. (1996). The New Competitor Intelligence. Chichester: John Wiley \& Sons.

Ghoshal, S., \& Westney, D.E. (1991). Organizing competitor analysis systems. Strategic Management Journal, 12, pp.17-31.

Gilad, B., \& T. Gilad. (1988). The Business Intelligence System: A New Tool for Competitive Advantage. New York: Amacom.

Grant, R.M. (1996). Toward a knowledge-based theory of the firm. Strategic Management Journal, 17 (Winter Special Issue), pp.109-22.

Gupta, A.K., \& Govindarajan, V. (1991). Knowledge flows and the structure of control within multinational corporations. Academy of Management Review, 16, pp.768-92.

Hedlund, G. (1994). A model of knowledge management and the N-form corporation. Strategic Management Journal, 15, pp.73-90.

Hedlund, G., \& Nonaka, I. (1991). Models of knowledge management in the West and Japan. Institute of International Business at the Stockholm School of Economics, RP 91/9. 
Kiker, B.F. (1966). The historical roots of the concept of human capital. Journal of Political Economy, 74, pp.481-99.

Knight, K., \& R.R. McDaniel. (1979). Organizations: An Information Systems Perspective. Belmont, CA: Wadsworth Publishing.

Lamersdorf, W. (1988). Office Knowledge: Representation, Management, and Utilization. Amsterdam: North-Holland.

Lave, J., \& E. Wenger. (1991). Situated Learning: Legitimate Peripheral Participation. Cambridge: Cambridge University Press.

Lessig, L. (1999). Code: and Other Laws of Cyberspace. New York: Basic Books.

Malone, T.W., \& Crowston, K. (1994). The interdisciplinary study of coordination. ACM Communication Surveys, 26 (1), pp.87-119.

Malone, T.W., Grant, K.R., Turbak, F.A., Brobst, S.A., \& Cohen, M.D. (1987). Intelligent information-sharing systems. Communications of the ACM, 30 (5), pp.390-402.

McCorduck, P. (1979). Machines Who Think: A Personal Inquiry into the History and Prospects of Artificial Intelligence. San Francisco, CA: W.H. Freeman and Company.

Michie, D. (1983). A prototype knowledge refinery. In J.E. Hayes \& D. Michie (Eds.), Intelligent Systems: The Unprecedented Opportunity. Chichester: Ellis Horwood.

Miller, R. (1996). Measuring What People Know: Human Capital Accounting for the Knowledge Economy. Paris: OECD.

Nishitani, K. (1991). Nishida Kitaro. Berkeley, CA: University of California Press.

Nonaka, I. (1988). Speeding organizational information creation: toward middle-up-down management. Sloan Management Review, (Spring), pp.57-73.

Nonaka, I. (1994). A dynamic theory of organizational knowledge creation. Organization Science, 5, pp.14-37.

Orr, J.E. (1990). Sharing knowledge, celebrating identity: community memory in a service culture. In D. Middleton \& D. Edwards (Eds.), Collective Remembering. (pp. 168-189). London: Sage.

Porter, M.E. (1980). Competitive Strategy: Techniques for Analyzing Industries and Competitors. New York: Free Press.

Prahalad, C.K., \& Hamel, G. (1990). The core competence of the corporation. Harvard Business Review, 68 (May-June), pp.79-91.

Quinn, J.B. (1992). Intelligent Enterprise: A Knowledge and Service Based Paradigm for Industry. New York: The Free Press.

Schon, D.A. (1963). Invention and the Evolution of Ideas. London: Social Science Paperbacks.

Schön, D.A. (1987). Educating the Reflective Practitioner: Toward a New Design for Teaching and Learning in the Professions. San Francisco, CA: Jossey-Bass Publishers.

Senge, P.M. (1990). The Fifth Discipline: The Age and Practice of the Learning Organization. London: Century Business.

Spender, J.-C. (1996). Making knowledge as the basis of a dynamic theory of the firm. Strategic Management Journal, 17 (Special Issue), pp.45-62.

Stanat, R. (1990). The Intelligent Corporation: Creating a Shared Network for Information and Profit. New York: AMACOM.

Suchman, L. (1987). Plans and Situated Actions: The Problem of Human-Machine Communication. New York: Cambridge University Press.

Sveiby, K.E. (1997). The New Organizational Wealth: Managing and Measuring Knowledge-Based Assets. San Francisco: Berrett-Koehler Publishers, Inc.

Tobin, J. (1978). Monetary policies and the economy: the transmission mechanism. Southern Economic Journal, 37 (April), pp.421-31. 
Tuomi, I. (1999). Corporate Knowledge: Theory and Practice of Intelligent Organizations. Helsinki: Metaxis.

Tuomi, I. (2002). Networks of Innovation: Change and Meaning in the Age of Internet. Oxford: Oxford University Press.

Tushman, M.L., \& Nadler, D.A. (1978). Information processing as an integrating concept in organizational design. Academy of Management Review, 3, pp.613-24.

Ungson, G.R., Braunstein, D.N., \& Hall, P.D. (1981). Managerial information processing: a research review. Administrative Science Quarterly, 26, pp.116-34.

Walsh, J.P., \& Ungson, G.R. (1991). Organizational memory. Academy of Management Review, 16, pp.57-91.

Watson, H.J., Rainer, R.K.Jr., \& Koh, C.E. (1991). Executive information systems: a framework for development and a survey of current practices. MIS Quarterly, March, pp.13-30.

Weick, K.E. (1995). Sensemaking in Organizations. Thousand Oaks: Sage Publications.

Winograd, T., \& F. Flores. (1986). Understanding Computers and Cognition: A New Foundation for Design. Norwood, NJ: Ablex Publishing Corporation. 